\title{
Seroprevalence of Hepatitis B Virus, Hepatitis C Virus and Human Immunodeficiency Virus in Children Undergoing Endoscopy in Our Pediatric Gastroenterology Clinic
}

\author{
Çocuk Gastroenteroloji Kliniğimizde Endoskopi Yapılan Hastalarda \\ Hepatit B Virüsü, Hepatit C Virüsü ve İnsan İmmünyetmezlik Virüsü \\ Seroprevalansı
}

\author{
Uğur Deveci'"(1̄īD) \\ ${ }^{1}$ Division of Pediatric Gastroenterology, Department of Pediatric, Firat University School of Medicine, Elazig, Turkey \\ ${ }^{2}$ Department of Public Health, Suruc Directorate of Health, Sanliurfa, Turkey
}

Cite this article as: Deveci U, Acar U. Seroprevalence of hepatitis B virus, hepatitis C virus and human immunodeficiency virus in children undergoing endoscopy in our pediatric gastroenterology clinic. J Pediatr Inf 2020;14(1):e5-e8.

\section{Abstract}

Objective: There is a risk of infection during interventional procedures such as endoscopy. Therefore, routine tests for infective pathogens before endoscopy and surgical procedures are very important in terms of protecting healthcare workers, determining the infection status of patients, and providing counseling, care and treatment services. The aim of this study was to evaluate the seroprevalence of hepatitis B virus (HBV), hepatitis $C$ virus (HCV) and human immune deficiency virus (HIV) infections of patients who underwent endoscopy.

Material and Methods: Demographic data and HBsAg, anti-HBs, anti-HCV and anti-HIV test results of the patients who underwent endoscopy between January 2017 and December 2017 in the pediatric gastroenterology department of our hospital were analyzed retrospectively.

Results: Of the 377 cases included in the study, 160 (42.4\%) were males and 217 (57.6\%) were females, with a mean age of $9.9 \pm 4.6$ (range: 1-18) years. Mean ages of the girls and boys were $10.3 \pm 4.7$ and $9.4 \pm 4.6$ years, respectively $(p>0.05)$. In our study, chronic hepatitis $C$ was detected in one and chronic hepatitis B infection in one patient. $63.9 \%$ of the cases were immune to hepatitis $B$ infection.

Conclusion: Seroprevalence of HBsAg, anti-HCV and anti-HIV in our study was not higher than the general population. However, all healthcare personnel should comply with infection control measures during interven-
Öz

Giriş: Endoskopi gibi girişimsel işlemler sırasında enfeksiyon bulaşma riski vardır. Bu nedenle, endoskopi ve cerrahi işlemlerden önce enfektif patojenlerin varlığına yönelik rutin testler sağlık çalışanlarının korunması ve hastaların enfeksiyon durumunun belirlenerek danışmanlık, bakım ve tedavi hizmetleri verilmesi yönünden oldukça önemlidir. Bu çalışma, endoskopi yapılan hastaların hepatit $B$ virüsü (HBV), hepatit $C$ virüsü (HCV) ve insan immünyetmezlik virüsü (HIV) enfeksiyonları yönünden değerlendirilmesi ve seroprevalanslarının saptanması amacıyla yapıldı.

Gereç ve Yöntemler: Hastanemiz çocuk gastroenteroloji bölümünde Ocak 2017-Aralık 2017 tarihleri arasında endoskopi yapılan hastaların demografik verileriyle birlikte $\mathrm{HBsAg}$, anti-HBs, anti-HCV ve anti-HIV test sonuçları retrospektif olarak incelendi.

Bulgular: Çalışmaya alınan 377 olgunun 160 (\%42.4)'ı erkek, 217 (\%57.6)'si kız olup bunların ortalama yaşı $9.9 \pm 4.6$ (sınır: 1-18) yıl idi. Kız çocukların yaş ortalaması $10.3 \pm 4.7$ yıl, erkek çocukların yaş ortalaması ise $9.4 \pm 4.6$ yıl bulunmuştur ( $p>0.05$ ). Çalışmamızda bir olguda kronik hepatit $C$ ve bir olguda ise kronik HBV enfeksiyonu saptanmıştır. Çalışmaya alınan olguların \%63.9'u HBV'ye karşı bağışık idi.

Sonuç: Çalışmamızdaki HBsAg, anti-HCV ve anti-HIV seroprevalanslarının genel toplumdan yüksek olmadığı görülmektedir. Buna karşın,

Correspondence Address/Yazışma Adresi

Uğur Deveci

Fırat Üniversitesi Tıp Fakültesi,

Çocuk Sağlığı ve Hastalıkları Anabilim Dalı,

Çocuk Gastroenteroloji Bilim Dalı,

Elazığ-Türkiye

E-mail: ugurdeveci23@hotmail.com 
tional procedures such as endoscopy, regardless of serological examinations of the patients. In addition, patients who do not have protective titer of anti-HBS should be vaccinated, and patients with infection should also be closely followed-up.

Keywords: Endoscopy, hepatitis B virus, hepatitis C virus, human immunodeficiency virus, seroprevalence, infection control

\section{Introduction}

Both physicians and patients are under risk of being infected by infections during invasive procedures like endoscopy and surgical interventions (1). Therefore, routine tests for infective pathogens before endoscopy and surgical procedures are very important in terms of protecting healthcare workers, determining the infection status of patients, and providing counseling, care and treatment services (2). Hepatitis B virus (HBV), hepatitis $\mathrm{C}$ virus (HCV) and human immunodeficiency virus (HIV) are agents commonly encountered that could be important causes of morbidity and mortality $(3,4)$. According to the records of the World Health Organization (WHO) on healthcare workers, every year 70.000 people are infected with HBV, 15.000 with HCV and 1000 with HIV due to sharp object injuries (5).

Thus, this study aimed to evaluate patients undergoing endoscopy in terms of $\mathrm{HBV}, \mathrm{HCV}$, and $\mathrm{HIV}$ infections and determine their prevalence in the Pediatric Gastroenterology Department of Şanlıurfa Training and Research Hospital.

\section{Materials and Methods}

Demographic data and HBsAg, anti-HBs, anti-HCV and anti-HIV test results of the patients who underwent endoscopy between January 2017 and December 2017 in the pediatric gastroenterology department of our hospital were analyzed retrospectively. Blood samples taken from patients planned to undergo endoscopy among those who applied to our clinic endoskopi gibi girişimsel işlemler sırasında hastaların serolojik tetkiklerinden bağımsız olarak tüm sağlık personelinin enfeksiyon kontrol önlemlerine uyması gerekir. Ayrıca, anti-HBS düzeyi koruyucu titrede olmayan hastaların aşılanması; enfeksiyon saptanan hastalar ise yakın takibe alınmalıdır.

Anahtar Kelimeler: Endoskopi, hepatit B virüsü, hepatit $C$ virüsü, insan immünyetmezlik virüsü, seroprevalans, enfeksiyon kontrolü

with various complaints were analyzed in terms of $\mathrm{HBsAg}$, anti-HBs, anti-HCV and anti-HIV parameters. Positivity of any serologic indicator was accepted as "seropositivity", and negativity of all serologic indicators was regarded as "seronegativity". SPSS 22.0 package program was used in the statistical analysis of these data. Numerical variables were expressed as mean \pm standard deviation, and categoric variables were expressed as percentage. Chi-square test and Fisher's exact test were used for statistical evaluation, and statistical significance was set at a $p$ value of $<0.05$.

\section{Results}

Of the 377 cases included in the study, 160 (42.4\%) were males and 217 (57.6\%) were females, with a mean age of $9.9 \pm$ 4.6 (range: 1-18) years. Mean ages of the girls and boys were $10.3 \pm 4.7$ and $9.4 \pm 4.6$ years, respectively ( $p>0.05)$. Sixty (15.9\%) of these cases were in the 1-4 age group, 104 (27.6\%) were in the 5-9 age group, 140 (31.7\%) were in the 10-14 age group, and 73 (19.4\%) were in the 15-18 age group (Table 1).

Of the samples sent, $\mathrm{HBsAg}(+) / \mathrm{anti}-\mathrm{HBs}(-), \mathrm{HBsAg}(-) / \mathrm{an}-$ ti-HBs (+), and HBsAg (-)/anti-HBs (-) serology was detected in 1, (0.3\%), $241(63.9 \%)$, and 135 (35.8\%) respectively. While anti-HCV was confirmed positive in $1(0.3 \%)$ of the samples, anti-HIV positivity was not determined in any of the samples (Table 2). When HBV and HCV serology was compared as regards patients' sex and age groups, a statistically significant difference was not found ( $p>0.05$ ) (Table 1).

Table 1. Distribution of HBsAg, anti-HBsAg, anti-HCV and anti-HIV serologic results of the cases in terms of sex and age groups ( $n=377$ )

\begin{tabular}{|c|c|c|c|c|c|c|c|}
\hline & \multicolumn{3}{|c|}{ HBV serology* } & \multicolumn{2}{|c|}{ Anti-HCV** } & \multicolumn{2}{|c|}{ Anti-HIV } \\
\hline & $\begin{array}{c}\text { HBsAg (+) } \\
\text { Anti-HBs (-) }\end{array}$ & $\begin{array}{c}\text { HBsAg (-) } \\
\text { Anti-HBs (+) }\end{array}$ & $\begin{array}{c}\text { HBsAg (-) } \\
\text { Anti-HBs (-) }\end{array}$ & $\begin{array}{c}\text { Positive } \\
\text { n (\%) }\end{array}$ & $\begin{array}{c}\text { Negative } \\
\text { n (\%) }\end{array}$ & $\begin{array}{c}\text { Positive } \\
\text { n (\%) }\end{array}$ & $\begin{array}{c}\text { Negative } \\
\text { n (\%) }\end{array}$ \\
\hline Male & $0(0.0)$ & $104(65.0)$ & $56(35.0)$ & $1(0.6)$ & 159 (99.7) & $0(0.0)$ & $160(100.0)$ \\
\hline Female & $1(0.5)$ & $137(63.1)$ & $79(36.4)$ & $0(0.0)$ & $217(100.0)$ & $0(0.0)$ & $217(100.0)$ \\
\hline 5-9 years & $0(0.0)$ & 69 (66.3) & 35 (33.7) & $0(0.0)$ & 104 (100.0) & $0(0.0)$ & $104(100.0)$ \\
\hline 10-14 years & $1(0.7)$ & $84(60.0)$ & 55 (39.3) & $1(0.7)$ & 139 (99.3) & $0(0.0)$ & $140(100.0)$ \\
\hline $15-18$ years & $0(0.0)$ & $40(54.8)$ & $33(45.2)$ & $0(0.0)$ & 73 (100.0) & $0(0.0)$ & $73(100.0)$ \\
\hline
\end{tabular}


Table 2. HBsAg, anti-HBsAg, anti-HCV and anti-HIV positivity rates of the cases

\begin{tabular}{|l|c|c|}
\hline Cases (n= 377) & $\begin{array}{c}\text { Number of positive } \\
\text { cases (n) }\end{array}$ & $\begin{array}{c}\text { Positivity percentage } \\
\text { (\%) }\end{array}$ \\
\hline HBsAg (+)/anti-HBs (-) & 1 & 0.3 \\
\hline HBsAg (-)/anti-HBs (+) & 241 & 63.9 \\
\hline HBsAg (-)/anti-HBs (-) & 135 & 35.8 \\
\hline Anti-HCV & 1 & 0.3 \\
\hline Anti-HIV & - & - \\
\hline \multicolumn{2}{|l}{} \\
\hline
\end{tabular}

Cases detected to have $\mathrm{HBsAg}$ and anti-HCV positivity were clinically diagnosed as chronic HCV and chronic HBV infection.

\section{Discussion}

Viral hepatitis remains an important health problem and economic burden worldwide. HBV and HCV are the most significant causes of chronic viral hepatitis in the world. Clinical findings tend to change according to the type of the virus and age of the patient. Although HBV and HCV infections in children are asymptomatic, there is a risk of cirrhosis and hepatocellular carcinoma development (6).

Early diagnosis and treatment of HBV and HCV infections can prevent mortality and morbidity. In addition, the detection of individuals with chronic infection and prevention of these infections to be spread are vital in terms of public health. Screening patients for infection prior to endoscopy and surgical procedures provides healthcare workers with the opportunity to early diagnosis, treatment and prevention of transmission of the infection (4).

Chronic HBV carrier rate in our country is $5-8 \%$ and is among the regions with moderate endemicity (7). HBsAg positivity was detected in one of the cases $(0.3 \%)$ in this study. During the follow-up of the case, more than 6-month $\mathrm{HBsAg}$ and HBV DNA positivity were observed, and the case was taken under follow-up with chronic HBV diagnosis. In a study by Demirel et al. conducted in Zonguldak, 1 (0.5\%) case have been detected HBsAg positive; whereas, Üstün et al. have reported HBsAg positivity in $1(0.4 \%)$ case in a study carried out in Mardin $(8,9)$. Tekin et al. have reported $3(0.5 \%)$ cases of HBsAg positivity in Mardin (10). Kaya et al. have confirmed 3 $(0.2 \%)$ cases having HBsAg positivity in Van (11). Again, in the same study, the authors have reported chronic HBV infection in $6(0.5 \%)$ children. Altan et al. have detected $34(0.8 \%)$ cases with $\mathrm{HBsAg}$ positivity in a study conducted in Ankara (12). Ayvaz et al. confirmed HBsAg positivity in $1(0.16 \%)$ case in Sivas in 2008 (13). Following the addition of HBV vaccination to the national immunization program in 1998 by the Ministry of Health, HBsAg seroprevalence has prominently diminished in our country.
Although the children included into the study were routinely vaccinated for HBV as regards the national immunization program, anti-HBs positivity rate was established as $63.9 \%$. Altan et al. determined anti-HBs positivity rate as $75.3 \%$ in a study they conducted in Ankara in 2017 (9). Suleyman et al. detected anti-HBs positivity as $96.2 \%$ in Istanbul in the year 2012 (12). In another study performed in Manisa in 2003 , anti-HBs positivity was found as $86.8 \%$ (15). In a study by Tekin et al. conducted in Mardin in 2010, the authors reported anti-HBs positivity as $85.1 \%$. Ayvaz et al., on the other hand, have reported anti-HBs positivity rate of $73.9 \%$ in Sivas (13). We are of the opinion that the low rate of anti-HBs positivity found in our study compared to other hospital-based studies was due to the education level of the parents and low socio-economic and socio-cultural level of the region, which affects the viewpoint to vaccination.

A serious health problem worldwide, HCV infection has been reported to have affected 170 million people. Approximately 7 million adults and 100.000 children have been established to be HCV infected in the United States of America (USA) (16). Moreover, HCV seroprevalence among children in the USA has been reported nearly 0.2-0.4\% (about 132.000 cases) (17). Again, in the same country, it has been reported that there are 23.048-42.996 chronic HCV infected children. 7200 new cases are determined every year (18). In our study, $1(0.3 \%)$ patient was confirmed anti-HCV positive. During the follow-up of the case, since more than 6-month anti-HCV and HCV RNA positivity were observed, the case was accepted as having chronic HCV infection. Having a major surgical intervention history in this case in our study suggests the importance of infection transmission measures taken during surgical intervention both for the patient and healthcare worker. Tekin et al. did not detect anti-HCV positivity in any of the pediatric cases in a study conducted in 2011 (10). Ayvaz et al. have reported only one case $(0.16 \%)$ with anti-HCV positivity in Sivas (13).

HIV infection in children occur vertically, in other words, it is transmitted from the mother to the child in the perinatal period. Furthermore, transmission routes such as HIV infected blood or blood product transmission or contact with materials contaminated by HIV have been reported. More than $90 \%$ of this infection in children are acquired in the perinatal period (19). No cases have been confirmed as anti-HIV positivity in several studies conducted on children in our country $(8,10)$. According to the data of the Ministry of Health, the. Number of children with HIV infection was reported as 1391 in the year 2013. When transmission routes of the cases in Turkey were examined, mother-to-child transmission was established in $10(0.7 \%)$ cases in 2013. Transmission routes of the other cases could not be detected (20).

According to the results of this study, HBsAg, anti-HCV and anti-HIV seroprevalences in pediatric cases undergoing 
endoscopy were observed not higher than the general population. Transmission risk of these agent will be decreased by taking measures considering the possibility of virus transmission regardless of the serologic tests of the patients during interventional procedures like endoscopy and surgical interventions. Anti-HBs value above $10 \mathrm{IU} / \mathrm{mL}$ is considered seropositivity after routine HBV vaccination. In cases that do not provide the sufficient antibody titer after primary immunization, the Ministry of Health recommends a second 3-doses HBV vaccination scheme (21). It has been reported even in individuals with no immune deficiency that antibody response at a rate of $5 \%$ was not sufficient after standard HBV vaccination (22).

It is evident that there is a need for parental education, raising public awareness regarding routine HBV vaccination, close monitoring of healthy children in terms of HBV, and broader scale studies for determining seroprevalences. During the study, appropriate immunization procedures of those not having sufficient protective anti-HBS titers were started, and the patients with chronic HBV and HCV infections were taken under close monitoring.

Ethics Committe Approval: Ethics committee approval was obtained for the study. Firat University, Ethics Committee for Noninvasive Research, Meeting dated: 01.03.2018 Meeting no: 5, Decision no: 16

Informed Consent: None due to the retrospective nature of the study.

Peer-review: External, independent.

Author Contributions: Concept - UD, UA; Design - TUD, UA; Supervision - UD; Data Collection and/or Processing - UA; Analysis and/or Interpretation - UD, UA; Literature Review - UA; Writing - TTK; Critical Review - All authors.

Conflict of Interest: No conflict of interest was declared by the authors.

Financial Disclosure: The authors declared that this study has received no financial support.

\section{References}

1. Banerjee S, Shen B, Nelson DB, Lichtenstein DR, Baron TH, Anderson MA, et al.; ASGE Standards of Practice Committee. Infection control during

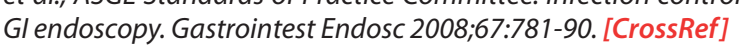

2. Ahmed $R$, Bhattacharya $S$. Universal screening versus universal precautions in the context of preoperative screening for HIV, HBV, HCV in India. Indian J Med Microbiol 2013;31:219-25. '[C Cross Re' $]_{1}$

3. Bozkurt S, Kökoğlu ÖF, Yanıt F, Kocahasanoğlu U, Okumuş M, Sucaklı $M H$ ve ark. Sağlık çalışanlarında iğne batması ve cerrahi aletlerle olan

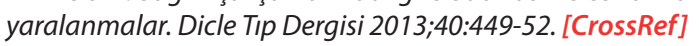

4. Beltrami EM, Williams IT, Shapiro CN, Chamberland ME. Risk and management of blood-borne infections in health care workers. Clin Microbiol Rev 2000;13:385-407. ['Cross'Ref]"
5. Phillips EK, Owusu-Ofori A, Jagger J. Bloodborne pathogen exposure risk among surgeons in sub-Saharan Africa. Infect Control Hosp Epidemiol 2007;28:1334-6. [C[ross Réf]'

6. Karnsakul W, Schwarz KB. Hepatitis B and C. Pediatr Clin North Am

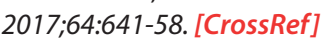

7. Gülşen $H H$, Yüce A. Viral Hepatitler. İçinde: Özen H, Yüce A, Gürakan F, Saltık Temizel iN, Demir H. Çocuk Gastroenteroloji, Hepatoloji ve Beslenme, 3. Baskı. Akademi Uluslararası Yayıncılık San. ve Tic. Ltd. Şti., 2016. p.237-68. [CrossRef]

8. Demirel F, Acun C, Söğüt A, Çınar F, Numanoğlu KV, Tomaç N. Elektif şartlarda cerrahi operasyon planlanan çocuk hastalarda hepatit $B$, hepatit C ve HIV seroprevalansı. Çocuk Dergisi 2003;3:200-3. [CrossRef]

9. Üstün C, Basuguy E, Deveci U. Çocuk cerrahi polikliniğine başvuran hastalarda hepatit $B$, hepatit $C$ seroprevalansı. Nobel Medicus 2009;5(ek 1):4-9. [CrossRef]

10. Tekin A, Aydoğdu B. Mardin Ilinde elektif cerrahi öncesi tetkik edilen çocuklarda HBV, HCV ve HIV seroprevalansı. Konuralp Tıp Derg 2011;3:7-11. [CrossRef]

11. Kaya A, Erbey MF, Okur M, Sal E, Üstyol L, Bektaş MS. Van yöresinde 0-18 yaşları arasındaki çocuklarda hepatit B virüsu seropozitifliği ve aşılama

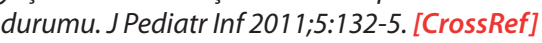

12. Altan H, Demirtaş $S$, Taş D, Budakoğlu Ii. Ankara'da bir devlet hastanesine başvuran çocuklarda hepatit B seroprevalansının belirlenmesi. Ankara Med J 2017;1:1-8.'[CrossRef]]

13. Ayvaz A, Nur N, Engin A, Çetinkaya S. Sivas il merkezinde yaşayan ilkokul birinci sınıf öğrencisi çocuklarda hepatit $B$, hepatit $C$ yaygınlığı. Türk Ped Arş 2010;45:132-6. "[C Cross Ref f]"

14. Süleyman A, Gökçay G, Badur S, Aykın S, Kılıcı G, Tamay Z. Süt çocukluğunda hepatit $B$ aşısı uygulanan çocuklarda serolojik durumun değerlendirilmesi. Mikrobiyol Bul 2012;46:47-56. [CrossRef]

15. Tosun SY, Eser E, Sır E, Bayındırı D, Irencin D, Obalı C. Manisa Illi Muradiye Sağlık Ocağı merkez bölgesinde 1998 yılında hepatit B aşılama programına alınan çocuklarda dört yıl sonraki aşı koruyuculuk düzeyinin araştırılması. MN Klinik Bilimler \& Doktor 2003;9:459-66. [CrossRef]

16. Jonas M. Children with hepatitis C. Hepatology 2003;36:S173-8. [CrossRef]

17. Alter MJ, Kruszon-Moran D, Nainan OV, McQuillan GM, Gao F, Moyer $L A$, et al. The prevalence of hepatitis $C$ virus infection in the United States, 1988 through 1994. N Engl J Med 1999;341:556-62. ['[Cross Ref $]_{1}^{\prime}$

18. Jhaveri R, Grant W, Kauf TL, McHutchison J. The burden of hepatitis C virus infection in children; estimated direct medical costs over a ten year period. J Pediatr 2006;148:353-8. "[C Cross Ref $]_{1}^{\prime \prime}$

19. Sütçü $M$, Somer A. Anneden bebeğe HIV geçişinin önlenmesi. Çocuk Dergisi 2014;14:138-42. [CrossRef]

20. T.C. Sağlık Bakanlığı. HIV/AIDS verileri, Ekim 1985-Haziran 2014. Türkiye Halk Sağlığı Kurumu, Bulaşıcı Hastalıklar Daire Başkanlığı, Zührevi Hastalıklar Birimi. Erişim: http://www.hatam.hacettepe.edu.tr/veriler_ Haziran_2014.pdf. [C] Cross'Ref]

21. T.C. Sağlık Bakanlığı Temel Sağlık Hizmetleri Genel Müdürlüğü. Hepatit B aşısı uygulaması hakkında genelge. 21-6-2000 / 8942. T.C. Sağlık Bakanıığı Temel Sağlık Hizmetleri Genel Müdürlüğü. Aşı takvimi değişikliği hakkında genelge. 29.09.2003 / 14408. T.C. Sağlık Bakanlığı Temel Sağlık Hizmetleri Genel Müdürlüğü Genișletilmiş Bağışıklama Programı Genelgesi (Daimi Genelge) 30.10.2006/16664. T.C. Sağlık Bakanlığı Temel Sağılı Hizmetleri Genel Müdürlüğü Genişletilmiş Bağışıklama Programı Genelgesi (Daimi Genelge) 25.02.2008, 2008/14 http://saglik.gov. tr/TR/dosya/1-33203/h/gbpgenelge2008.pdfi[Cross Ref $]_{1}^{\prime}$

22. Walayat S, Ahmet Z, Martin D, Puli S, Cashman M, Dhillon S. Recent advances in vaccination of non-responders to standard dose hepatitis $B$ virus vaccine. World J Hepatol 2015;7:2503-9.'['CrossRef] 